\title{
Effect of $N$-acetyl-L-cysteine on human chronic myeloid leukemia cells KCL22 treated with mitomycin C
}

\author{
Anna Simonyan ${ }^{1}$, Galina Hovhannisyan ${ }^{1}$, Rouben Aroutiounian ${ }^{1}$ and Jin Kyu Kim ${ }^{2,3, *}$ \\ ${ }^{1}$ Dept. of Genetics and Cytology, Faculty of Biology, Yerevan State University, A. Manoukian st.1, Yerevan, Armenia \\ ${ }^{2}$ Korea Atomic Energy Research Institute, Advanced Radiation Technology Institute, Jeongeup 580-185, Korea \\ ${ }^{3}$ University of Science and Technology, Daejeon 305-350, Korea
}

\begin{abstract}
The effectiveness of $\mathrm{N}$-acetyl-L-cysteine (NAC) to protect blood cells against Mitomycin C (MMC) induced genotoxicity was investigated in human chronic myeloid leukemia cells (KCL22) using the alkaline comet assay. The comet assay was selected as sensitive and rapid method for analysis of DNA damage and repair in individual cells. NAC treatment alone did not produce any damage in KCL22 cell. But NAC was found to be effective in reducing genotoxic damage in KCL22 cells exposed to MMC. These results confirm the literature data that, given the safety and ability to reduce DNA damage. NAC may be useful to prevent drug-mediated genotoxicity.
\end{abstract}

Key words: comet assay, genotoxicity prevention, mitomycin C, $N$-acetyl-L-cysteine

\section{INTRODUCTION}

The chemotherapeutic agents usually exert severe side toxic effects. The use of some pharmacological and dietary compounds to protect organs that are not targets in association with chemotherapy has been encouraged. Mitomycin $\mathrm{C}(\mathrm{MMC})$ has a wide clinical antitumor spectrum with efficacy in various tumor types. Metabolism of MMC leads to generation of mono- and bi-functional alkylating species and/or reactive oxygen species (ROS). DNA alkylation results in both inter- and intra-strand cross-linking of two nucleic acid chains and linking nucleic acid to protein, which could be a major factor for the disruption of nucleic acid functions (Tomasz 1995, Pawar et al. 2009).

The protective features (related to antioxidant activity) of $N$-acetyl-L-cysteine (NAC) towards DNA were earlier shown against DNA damaging agent in HepG2 cell line in vitro (Yedjou et al. 2010). It has anticarcinogenic, antioxidant and detoxifying activity and has been in clini- cal practice for several decades (Samuni et al. 2013). NAC belongs to low-molecular-weight thiols. Its cytotoxic, cytostatic and apoptosis-inducing activities were demonstrated in several different types of cancer cells (Wadhwa and Mumper 2013). Many years of experience in the prophylaxis and therapy of a variety of clinical conditions have established the safety of this drug, even at very high doses and for long-term treatments.

MMC has been widely used against various solid tumours. Thus, strategies for minimizing the toxicity of MMC as well as other antitumor drugs using antioxidant and antigenotoxic compounds are of clinical interest. Earlier the possibility to protect against MMC-induced oxidative stress was shown in Vero cells (Rjiba-Touati et al. 2013).

Blood cells are particularly susceptible to the effects of chemotherapy. Because of this, in the present study,

\section{http://dx.doi.org/10.5141/ecoenv.2014.004}

\footnotetext{
This is an Open Access article distributed under the terms of the Creative Commons Attribution Non-Commercial Licens (http://creativecommons.org/licenses/by-nc/3.0/) which permits unrestricted non-commercial use, distribution, and reproduction in any medium, provided the original work is properly cited.
}

Received 27 January 2014, Accepted 17 February 2014

\footnotetext{
*Corresponding Author

E-mail: jkkim@kaeri.re.kr Tel: +82-63-570-3130
} 



Fig. 1. Representative images from comet assay. (a) Control, (b) MMC (1 $\mu \mathrm{g} / \mathrm{mL})$, (c) NAC (500 $\mu M)+M M C(1 \mu \mathrm{g} / \mathrm{mL})$.

we evaluate effectiveness of NAC to protect blood cells against MMC genotoxicity using the alkaline comet assay in human chronic myeloid leukemia cells (KCL22).

\section{MATERIALS AND METHODS}

\section{Cell line incubation and treatment}

The cell line KCL22 (i.e., suspension cell line of human chronic myeloid leukemia in blast crisis) provided by Dr. T. Liehr (Institute of Human Genetics, Germany) was used in the experiment. Cells were routinely maintained in the growth medium RPMI-1640 supplemented with $10 \%$ fetal bovine serum (Sigma-Aldrich, Seelze, Germany; Biochrom AG, Berlin, Germany) at $37^{\circ} \mathrm{C}$. Cells were seeded into $15 \mathrm{~mL}$ glass vials at the concentration $0.5 \times 10^{6} \mathrm{cell} /$ $\mathrm{mL}$ ( $2 \mathrm{~mL}$ of cell suspension per vial) and incubated for $24 \mathrm{~h}$. NAC solved in water was added to the cell cultures at the final concentrations 100,500 and $1000 \mu \mathrm{M}$ for $24 \mathrm{~h}$. The concentrations of NAC were chosen on the basis of the literature data and our preliminary experiments. After incubation with NAC cells were treated with MMC (1 $\mu \mathrm{g} / \mathrm{mL}$ ) for $2 \mathrm{~h}$. Concentration and time treatment were determined in our preliminary experiments as optimal to induce moderate level of DNA damage in KCL22 cells.

\section{Comet assay}

The level of DNA damage was evaluated by standard alkaline single-cell gel electrophoresis (comet assay) (Tice et al. 2000). $20 \mu \mathrm{L}$ of cell suspensions mixed with $0.5 \%$ low-melting agarose $(80 \mu \mathrm{L})$ were added to slides precoated with $1 \%$ normal-melting agarose. After the solidification of gel layer the slides were immersed in a lysis solution (2.5 M NaCl, 100 mM EDTA disodium salt ( $\mathrm{pH} 8.0$ ),
$10 \mathrm{mM}$ Tris buffer (pH 10.0) and $1 \%$ TritonX-100) at $4^{\circ} \mathrm{C}$ for $60 \mathrm{~min}$. Slides were placed in electrophoresis buffer (0.3 M NaOH, 1 mM Na 2 EDTA, pH 13) to allow DNA to unwind. Electrophoresis was performed for $20 \mathrm{~min}$ at $300 \mathrm{~mA}$ and $1 \mathrm{~V} / \mathrm{cm}$. Slides were neutralized with Tris- $\mathrm{HCl}$ buffer, $\mathrm{pH} 7.5$, and stained with $20 \mu \mathrm{g} / \mathrm{mL}$ ethidium-bromide for $10 \mathrm{~min}$.

Slides were examined at $\times 250$ magnifcation on an Axiophot fluorescent microscope (Zeiss, Oberkochen, Germany). At least 150 cells were scored per animal (50 cells scored per each of three replicate slides). Images of comets were recorded with a Variocam video camera with high sensitivity (PCO, Kelheim, Germany) and processed on a computer program Comet Assay IV ver. 4.3 (Perceptive Instruments, Bury St Edmunds, UK). Tail moment and tail intensity are used to evaluate the extent of DNA damage.

Statistical analysis of the results was performed using SPSS ver. 19 (SPSS Inc., Chicago, IL, USA) with application of non-parametric Mann-Whitney test (U test).

\section{RESULTS}

The various parameters of the comet assay in KCL22 cells treated with NAC and MMC are presented in Table 1. The observed tail length (TL), Olive tail moment (OTM) and percentage DNA in tails (\% DNA tail) in MMC-treated cells were significantly $(P<0.05)$ higher than in the negative controls (Fig. 1).

All of the tested doses of NAC were effective in exerting significant protection against the genotoxicity of MMC as evident from a reduction in the observed TL, OTM and \% DNA tail, compared to the positive control. With increasing concentration of NAC from 100 to $500 \mu \mathrm{M}$, protective effect is essentially enhanced. NAC at $1000 \mu \mathrm{M}$ induced further decrease of \% DNA tail and minor increase in TL 
and OTM. Thus, the concentration of NAC $500 \mu \mathrm{M}$ can be considered as the most effective.

NAC treatment alone did not produce any damage to the KCL22 cell at doses investigated.

Findings from these studies demonstrated that under this condition, NAC was found to be effective in reducing genotoxic damage in KCL22 cells exposed to MMC.

\section{DISCUSSION}

This study evaluated the protective effects of NAC on DNA damage induced by MMC by means of the singlecell gel electrophoresis (comet) assays. Pre-treatment of NAC at the tested doses significantly reduced the DNA damage induced by MMC in KCL22 cells as indicated by the decrease in the comet parameters TL, OTM and \% DNA tail.

The comet assay was selected for our study as sensitive and rapid method for analysis of DNA damage and repair in individual cells. For the realization of this method cells are embedded in a thin layer of agarose on a glass slide, and then lysed. Thus membranes and soluble cell constituents, as well as histones, are removed, leaving the DNA still super coiled and attached to the nuclear matrix. Subsequent alkaline incubation and electrophoresis causes DNA loops containing breaks to move towards the anode, forming a 'comet tail' when visualized by fluorescence microscopy. The images resemble comets, and the relative content of DNA in the tail indicates the frequency of breaks (Dusinska and Collins 2008). The simple principle of DNA breaks detection makes it a good technique for studying of cellular responses to genotoxic and antigenotoxic agents in vitro and in vivo (Pawar et al. 2009, Furtado et al. 2010, Erdem et al. 2012).

MMC mainly induces DNA-DNA interstrand crosslinks. However, an increase in DNA migration in the comet assay was shown in human blood cells (Pfuhler and Wolf 1996). This result may be explained by the ability of MMC to form hydrogen peroxide and hydroxyl radicals after reductive bioactivation (Dorr 1988). The comet assay detects $\mathrm{H}_{2} \mathrm{O}_{2}$-induced DNA breaks with high sensitivity (Fairbairn et al. 1995), even a small amount of $\mathrm{H}_{2} \mathrm{O}_{2}$ being sufficient for the induction of measurable DNA damage. Therefore, the protective effect of NAC against MMC can be attributed to its ability to scavenge the reactive oxygen species, hence preventing direct mutagenicity and DNA damages (Yedjou et al. 2010).

NAC has been shown to exert protective effects in a variety of experimental test systems. It is particularly important that NAC displays an ability to protect against DNA damage and in the same time was not effective in protection against cytotoxicity in different test-systems (Lewerenz et al. 2003, Reliene et al. 2009, Kim et al. 2013). This ability of NAC is very promising to decrease severe genotoxic side effect of antitumor drugs in normal cells without reduction of their treatment efficiency, mainly based on cytotoxic activity. Given these properties, NAC has the potential to be used as a selective protector against genotoxicity in normal tissue during radiotherapy or chemotherapy.

In conclusion, we have demonstrated that NAC supplement may effectively diminish MMC-induced DNA damage in KCL22 cells, possibly by scavenging ROS induced by MMC. Also, the protective action of NAC through other mechanisms is not excluded. These results confirm the literature data that, given the safety and efficacy of NAC, it may be useful to prevent drug-mediated genotoxicity.

Table 1. Protective effect of $\mathrm{NAC}^{\S 1}$ against $M \mathrm{MC}^{\S 2}$-induced DNA damage in the KCL22 cells

\begin{tabular}{|c|c|c|c|c|c|c|}
\hline \multirow{2}{*}{ Treatment } & \multicolumn{2}{|c|}{ Tail Length $(\mu \mathrm{m})$} & \multicolumn{2}{|c|}{$\%$ DNA tail ${ }^{\S 3}$} & \multicolumn{2}{|c|}{ Olive Tail Moment } \\
\hline & Mean $\pm S E$ & Median & Mean \pm SE & Median & Mean $\pm S E$ & Median \\
\hline Control & $49.2 \pm 1.65$ & 44.86 & $11.89 \pm 1.32$ & 4.76 & $2.86 \pm 0.45$ & 1.11 \\
\hline NAC $(100 \mu \mathrm{M})$ & $41.36 \pm 0.74$ & 40.1 & $10.51 \pm 1.2$ & 4.54 & $1.99 \pm 0.23$ & 0.81 \\
\hline NAC $(500 \mu \mathrm{M})$ & $48.4 \pm 0.96$ & 46.85 & $9.4 \pm 1.18$ & 4.27 & $2.29 \pm 0.37$ & 0.96 \\
\hline NAC $(1000 \mu \mathrm{M})$ & $45.2 \pm 2.3$ & 40.2 & $14.5 \pm 1.48$ & 1.53 & $3.35 \pm 0.53$ & 1.52 \\
\hline MMC (1 $\mu \mathrm{g} / \mathrm{mL})$ & $85.4 \pm 4$ & $70.38^{\mathrm{a}}$ & $27.16 \pm 1.97$ & $23.01^{\mathrm{a}}$ & $11.38 \pm 1.4$ & $6.46^{\mathrm{a}}$ \\
\hline $\mathrm{NAC}(100 \mu \mathrm{M})+\mathrm{MMC}(1 \mu \mathrm{g} / \mathrm{mL})$ & $54.5 \pm 1.16$ & $51.93^{*}$ & $11.74 \pm 0.9$ & $10.1^{*}$ & $2.86 \pm 0.23$ & $2.3^{*}$ \\
\hline $\mathrm{NAC}(500 \mu \mathrm{M})+\mathrm{MMC}(1 \mu \mathrm{g} / \mathrm{mL})$ & $42.98 \pm 1.83$ & $39.11^{*}$ & $10.05 \pm 1.2$ & $2.74^{*}$ & $2.7 \pm 0.6$ & $0.53^{*}$ \\
\hline NAC $(1000 \mu \mathrm{M})+\mathrm{MMC}(1 \mu \mathrm{g} / \mathrm{mL})$ & $43.05 \pm 1.54$ & $40.33^{*}$ & $9.5 \pm 1.03$ & $1.1^{*}$ & $2.17 \pm 0.36$ & $1.05^{*}$ \\
\hline
\end{tabular}

${ }^{a} P<0.05$ significantly different from control.

${ }^{*} P<0.05$ significantly different from samples treated with MMC.

${ }^{\$ 1}$ NAC, $N$-acetyl-L-cysteine.

$\$ 2$ MMC, mytomycin C.

$\$ 3 \%$ DNA tail, percentage of DNA content in the comet tail. 


\section{ACKNOWLEDGMENTS}

This study has been carried out under the collaboration between Yerevan State University and Korea Atomic Energy Research Institute, and also under the Creative Research Program by the Ministry of Science, ICT and Future Planning (MSIP) of Korea.

\section{LITERATURE CITED}

Dorr RT. 1988. New findings in in the pharmacokinetic, metabolic and drug-resistance aspects of mitomycin C. Semin Oncol 15: 32-41.

Dusinska M, Collins AR. 2008. The comet assay in human biomonitoring: gene-environment interactions. Mutagenesis 23: 191-205.

Erdem MG, Cinkilic N, Vatan O, Yilmaz D, Bagdas D, Bilaloglu R. 2012. Genotoxic and anti-genotoxic effects of vanillic acid against mitomycin C-induced genomic damage in human lymphocytes in vitro. Asian Pac J Cancer Prev 13: 4993-4998.

Fairbairn DW, Olive PL, O'Neill KL. 1995. The comet assay: a comprehensive review. Mutat Res 339: 37-59.

Furtado RA, de Araújo FR, Resende FA, Cunha WR, Tavares DC. 2010. Protective effect of rosmarinic acid on V79 cells evaluated by the micronucleus and comet assays. J Appl Toxicol 30: 254-259.

Kim JK, Park J, Ryu TH, Nili M. 2013. Effect of $N$-acetyl-1cysteine on Saccharomyces cerevisiae irradiated with gamma-rays. Chemosphere 92: 512-516.

Lewerenz V, Hanelt S, Nastevska C, El-Bahay C, Röhrdanz E, Kahl R. 2003. Antioxidants protect primary rat hepatocyte cultures against acetaminophen-induced DNA strand breaks but not against acetaminophen-induced cytotoxicity. Toxicology 191: 179-187.

Pawar AA, Vikram A, Tripathi DN, Padmanabhan S, Ramarao P, Jena G. 2009. Modulation of mitomycin C-induced genotoxicity by acetyl- and thio- analogues of salicylic acid. In Vivo 23: 303-307.

Pfuhler S, Wolf HU. 1996. Detection of DNA-crosslinking agents with the alkaline comet assay. Environ Mol Mutagen 27: 196-201.

Reliene R, Pollard JM, Sobol Z, Trouiller B, Gatti RA, Schiestl RH. 2009. N-acetyl cysteine protects against ionizing radiation-induced DNA damage but not against cell killing in yeast and mammals. Mutat Res 665: 37-43.

Rjiba-Touati K, Ayed-Boussema I, Soualeh N, Achour A, Bacha H, Abid S. 2013. Antioxidant and antigenotoxic role of recombinant human erythropoeitin against alkylating agents: cisplatin and mitomycin C in cultured Vero cells. Exp Biol Med (Maywood) 238: 943-950.

Samuni Y, Goldstein S, Dean OM, Berk M. 2013. The chemistry and biological activities of $\mathrm{N}$-acetylcysteine. Biochim Biophys Acta 1830: 4117-4129.

Tice RR, Agurell E, Anderson D, Burlinson B, Hartmann A, Kobayashi H, Miyamae Y, Rojas E, Ryu JC, Sasaki YF. 2000. Single cell gel/comet assay: guidelines for in vitro and in vivo genetic toxicology testing. Environ Mol Mutagen 35: 206-221.

Tomasz M. 1995. Mitomycin C: small, fast and deadly (but very selective). Chem Biol 2: 575-579.

Wadhwa S, Mumper RJ. 2013. D-penicillamine and other low molecular weight thiols: review of anticancer effects and related mechanisms. Cancer Lett 337: 8-21.

Yedjou CG, Tchounwou CK, Haile S, Edwards F, Tchounwou PB. 2010. N-acetyl-cysteine protects against DNA damage associated with lead toxicity in HepG2 cells. Ethn Dis 20 (Suppl 1): S101-S103. 